\title{
Whistleblower Protection as An Anti-Corruption Tool in Nigeria
}

\author{
Oluwakemi Omojola \\ Research Fellow, Nigerian Institute of Advanced Legal Studies, University of Lagos Nigeria
}

\begin{abstract}
Corruption gives a few what belongs to all thereby laying the foundation for poverty, crime and erosion of trust in government and its institutions. It is a malaise that has plagued Nigeria for an uncomfortable length of time and its stifling effect can be seen in different sectors and States of the Federation. It is an annoying recurring narrative in the national discourse of the nation Different anti-corruption initiatives and agencies such as the Economic and Financial Crimes Commission (EFCC) and Independent Corrupt Practices Commission (ICPC) have not been able to effectively tackle the problem. This paper examines the potential of the Whistleblowing Policy to curb corruption in Nigeria and the sustainability of the success of the Whistleblowing Policy. The paper finds that without a robust legislative framework to protect whistleblowers,the Whistleblowing Policy will suffer serious setbacks.
\end{abstract}

Keywords: Corruption, Whistleblowing, Whistleblower Protection, Legislation

DOI: $10.7176 / J L P G / 92-18$

Publication date: December $31^{\text {st }} 2019$

\subsection{Introduction}

Corruption is a global problem that has been with man since time immemorial. Corruption promotes poverty, insecurity, underdevelopment and political instability. Nigeria is the 136 least corrupt nation out of 175 countries ${ }^{1}$ and has been described in a few words as 'fantastically corrupt' ${ }^{2}$ Corruption cuts across all facets of the society and exists in the political, economic, social, religious, and cultural spheres. ${ }^{3}$ According to Ijewereme what is worrisome is the fact that most of the Nigerian rulers who came in as physicians to tackle the problem of corruption have come out as patients. ${ }^{4}$ Successive Governments have introduced various measures to curb corruption in the public sector. In 1976, the Public Officer Investigation of Asset Decree No. 5; Forfeiture of Assets Decree No. 53 of 1999 were introduced. The use of tribunal like the Failed Bank Tribunal set up by the regime of General Abacha, the Code of Conduct Bureau and the Code of Conduct Tribunal in 1979 amongst others. The Independent Corrupt Practices Commission (ICPC) and the Economic and Financial Crimes Commission (EFCC) were also set up to complement governments effort in tackling corruption. In its effort to fight corruption, the Nigerian Government introduced the Whistleblowing Policy as an anti-corruption tool. ${ }^{5}$

The Federal Government's Whistleblowing Policy consists of three parts. The first part deals with the channel and type of information that borders on authentic information about violation, misconduct, or improper activity which can negatively impact on Nigerians. The second part is hinged on the reward system. The whistleblower will get between 2.5 percent to 5 percent of the recovered loot. The third part entails protection from harassment, intimidation or victimisation and restitution for any loss suffered. ${ }^{6}$

The anti-corruption potential of the Whistleblowing Policy is not in doubt. What is however in doubt is the sustainability of the policy. Is the whistleblower adequately protected from retaliation under the present policy in Nigeria? Whistleblowers are exposed to different levels of risk and may be threatened, fired, sued, arrested, or even killed. Members of the family of a whistleblower are also at risk. This paper examines the sustainability of the extant Whistleblowing Policy in Nigeria as an anti- corruption tool and finds that the government put the cart before the horse without an enabling legislative framework to drive the Policy. This paper further advocates that the Whistleblower Protection Bill 2015 be reviewed to incorporate International Best Practice before enactment.

\subsection{Whistleblowing}

Ralph Nader defines whistleblowing as "an act of a man or woman who, believing that the public interest overrides the interest of the organization he serves, blows the whistle that the organization is in corrupt, illegal,

\footnotetext{
${ }^{1}$ Transparency International Corruption Index 2016 Available http://www.transparency.org/news/feature/corruption_perceptions_index_ ( May 14, 2017).

2 A. Eribake, 2016 Vanguard Newspaper 'Nigeria is Fantastically Corrupt - Uk's Prime Minister David Cameron Available http://www.vanguardngr.com/2016/05/nigeria-is-fantastically-corrupt-uks-prime-minister-david-cameron accessed May16 2017.

${ }^{3}$ N. J. Udombana, Fighting Corruption Seriously? (2003) , Africa's Anti-Corruption Convention 7 Singapore Journal of International and Comparative Law 449.

4 Ijereweme, O. (2015) Anatomy of Corruption in The Nigerian Public Sector, Theorectical Perspectives and Some Empirical Explanations [ Online] Available http://journals.sagepub.com/doi/pdf/10.1177/2158244015581188 June 182017.

${ }^{5}$ Ibid.

${ }^{6}$ N. Akinnaso, Punch Newspaper, 'Nigeria’s Whistleblower Policy' Available http://punchng.com/nigerias-whistle-blower-policy June 15 2017.
} 
fraudulent or harmful activity". ${ }^{1}$ This definition restricts whistleblowing to reporting corrupt activities by a current employee. It is "the disclosure by organization members (former or current) of the illegal, immoral or illegitimate practices under the control of their employers to persons or organizations that may be able to effect action. $^{2}$ Transparency International defines it as the disclosure of information related to corrupt, illegal, fraudulent or hazardous activities being committed in or by public or private sector organisations which are of concern to or threaten the public interest to individuals or entities believed to be able to effect action. ${ }^{3}$

A common thread that runs through these definitions is that whistleblowing takes into account public interest in exposing corruption. The overall common good that accrues to the public when someone blows the whistle is a fundamental feature.

A whistleblower is not motivated by personal gains. According to Schultz and Harutyunyan, ${ }^{4}$ whistleblowing is not a vengeful act done simply for embarrassing another, it excludes individuals who potentially blow the whistle simply or solely for economic gain. Banisar ${ }^{5}$ advocates for a more encompassing definition that takes into account whistleblowing as a process rather than a single act of disclosure. He defines whistleblowing as "a means to promote accountability by allowing for the disclosure by any person of information about misconduct while at the same time protecting the person against sanctions of all forms. This definition takes into cognisance the whistleblower's protection from the onset. Luxford is of the opinion that when whistleblowing is examined as a process the laws and policies driving it should embody the following :

- what types of perceived wrongdoing should be disclosed;

- to whom such disclosures should be made initially and subsequently (if the initial disclosure does not prompt an investigation);

- how and by whom the alleged wrongdoing should be investigated;

- the mechanisms and procedures that are in place to encourage persons to disclose wrongdoing while protecting the whistleblower from any disciplinary action or adverse consequence for reporting the wrongdoing and

- the steps to be taken if adverse consequences are, or appear to be, imposed on the whistleblower. ${ }^{6}$

\subsection{Whistleblower}

A whistleblower is an individual who, having disclosed information about illicit or non-compliant activities, or activities harmful to the public interest, and facing consecutively serious retaliations or threats thereof, including within its professional framework, necessitates a protection interest ${ }^{7}$. This includes individuals who are outside the traditional employee-employer relationship, such as consultants, contractors, trainees/interns, volunteers, student workers, temporary workers and former employees. There are two types of whistleblowers, the Internal whistleblower who is an employee of organization that report misconducts of their colleagues or superiors, and the external whistleblower who reports misconduct to persons outside of organization or certain institutions such as the media, police, and prosecution agencies. ${ }^{8}$

\subsection{Corruption}

The Corrupt Practices and Other Related Offences Act ${ }^{9}$ defines corruption to include bribery, fraud and other related offences. It is difficult to find a universally accepted definition of corruption. It is clear that corruption is the single greatest obstacle to economic and social development. World Bank describes it as the abuse of public office for private gains. Public office is abused for private gain when an official accepts, solicits or extorts a bribe. It is also abused when private agents actively offer bribes to circumvent public policies and processes for competitive advantage and profit. Public office can also be abused for personal benefit even if no bribery occurs

\footnotetext{
${ }^{1}$ Nader, R Petkas P. Blackwell K. (eds). (1972) Whistleblowing: The Report of the Conference on Professional Responsibility. New-York, Grossman, , pp 3-5.

2 Micelli, P . .Near P,' (1985) Organisational Dissidence The Case of Whistleblowing 4 J Bus Ethics 1 at 4.

3 International Principles for $\quad$ Whistleblower Protection

https://www.transparency.org/whatwedo/publication/international_principles_for_whistleblower_legislation (June 10 2017).

4 .Schultz, D. Harutyunyan , K (2015). 'Combating Corruption: The development of Whistleblowing Laws in United States, Europe and Armenia, International Comparative Jurisprudence Vol. 1 Iss. 2

${ }^{5}$ Banisar, D ."Whistleblowing: International Standards and Developments" in Irma E Sandoval, (eds), (2011) Corruption and Transparency: Debating the Frontiers between State, Market, and Society (Washington, DC: World Bank, Institute for Social Research, UNAM, Available http://ssrn.com/abstract_id=1753180 (June 10 2017).

${ }^{6}$ Luxford, V. Whistleblower Protection Available http://icclr.law.ubc.ca/sites/icclr.law.ubc.ca/files/publications/pdfs/Chapter\%2012\%20.pdf ( June 10 2017).

The United Nations Guiding Principles on Business and Human Rights (UNGP)< https://businesshumanrights.org/sites/default/files/media/documents/a-poitevin-submission-unwgbhr-whistleblowers-feb-2014.pdf June 142017.

${ }^{8}$ Matekovic, D., The Protection of Whistleblower Available https://www.pravo.unizg.hr/_download/repository/5._Domagoj_Matekovic_The Protection_of Whistleblowers\%5B1\%5D.pdf (June 12 2017)

${ }^{\overline{9}} \mathrm{Cap}$ C31, LFN, 2004 .
} 
through patronage and nepotism, the theft of state assests or the diversion of state revenue. ${ }^{1}$

According to Waziri the effect of corruption range from under development, absence of basic infrastructure such as potable water, good road networks, misappropriation of national resources leading to massive poverty. ${ }^{2}$ He adds further that, mediocrity in leadership, cluelessness in professionalism, deficient leadership outputs, high unemployment, continuous widening gap between the rich and poor result from corruption. The Whistleblowing Policy is an unconventional tool to fight corruption introduced in December 2016 and according to the Ministry of Finance it received 2351 tips from whistleblowers bordering on cases of embezzlement of public funds. ${ }^{3}$

\subsection{International Protection of Whistleblower}

Global and regional protection of whistleblowers highlights the increasing importance that the international community place on whistleblowing as an anti-corruption tool. The Inter-American Convention against Corruption (IACC) which is the first inter-governmental agreement to tackle whistleblower protection stress the importance of whistleblower protection as an anti-corruption tool. Member States are enjoined to establish and strengthen mechanisms protecting persons who disclose corrupt practices. ${ }^{4}$ The United Nations Convention Against Corruption (UNCAC), enjoins State Parties to take domestic measures to incorporate in their legislations and other provisions protection of whistleblower, witnesses and their families from any unwarranted treatment. The countries are also urged to set in place measures that facilitate reporting of corruption to appropriate agencies. ${ }^{5}$ It further states in article 32 that State Parties provide effective mechanism for protecting witnesses who disclose wrongdoing and their relatives from actual or potential harassment, retaliation or intimidation.

The Council of Europe Civil and Criminal Law Conventions on Corruption states in its Civil Law Convention that "each Party shall provide in its internal law for appropriate protection against any unjustified sanction for employees who have reasonable grounds to suspect corruption and who report in good faith their suspicion to responsible persons or authorities. ${ }^{6}$

The African Union Convention on Preventing and Combating Corruption (AUCPC 2003) in its preamble recognizes the detrimental effects that corruption has on the stability of African counties and its peoples. It noted the potential of whistleblowing as an anti- corruption mechanism and enjoins States to adopt legislative measures to punish those who make false and malicious reports against innocent persons in corruption and related offences.

\subsection{Domestic Protection of Whistleblower}

There are national legislations and policies that have provisions protecting a whistleblower. The Freedom of Information Act $(\mathrm{FOI})^{8}$ in section 27 protects public officers from criminal and civil proceedings for disclosures made in good faith. The information volunteered can be in respect of financial crime, abuse of authority, violation of laws and danger to health and safety. The public officer however is still at risk of suspension or demotions and even bodily danger as a result of making a disclosure. It is noteworthy that the the FOI Act does not extend protection to private sector workers.

The Terrorism (Prevention) Amendment Act 2013 in section 33 provides for the protection of the identity and life of a person who gives information to law enforcement agencies in investigating and prosecuting offences under the Act. It provides that reasonable measures to protect the identity and life of that person and the information volunteered shall be treated as confidential.' It is doubtful that a whistleblower who volunteers information not related to specific terrorism issues will be protected by the Act.

Section 64 of the independent Corrupt Practices and other Related Offences (ICPC) Act $2000^{9}$ provides that the information and the identity of a person from whom information is received by an officer of the commission shall be kept secret between them and all other circumstances relating to the information.

The Central Bank of Nigeria (CBN) in its Guidelines for Whistleblowing for Banks and Discount Houses in section 5.3.1 states that Banks shall have a whistleblowing policy made known to employees and other stakeholders. It states further that the policy shall contain mechanisms, including assurance of confidentiality that encourage all stakeholders to report any unethical activity to the bank and/or the CBN. ${ }^{10}$

\footnotetext{
1 World Bank, Available www1.worldbank.org/publicsector/anticorrupt/corruptn/cor02.htm (June 29 2017).

2 Waziri, F. (2010) .Corruption and Governance Challenges, Nigeria Conference Proceedings, Monograph Series, No. 7, CLEEN Foundation, Abuja, Nigeria

3 Odunsi, W. Daily Post Nigeria, Government Receives 2351 tips Available http://dailypost.ng/2017/03/25/whistle-blowing-nigeriangovernment-receives-2351-tips (June 8 2017).

${ }^{4}$ Article 3 (8).

${ }_{6}^{5}$ Article 33.

${ }^{6}$ Articles 9 for Civil Law Convention \& 22 for Criminal Law Convention.

${ }^{7}$ Article 5(6) .

${ }^{8}$ FOI Act 2011

${ }^{9}$ ICPC Act 2000

10 CBN Guideline for Whistleblowing for Banks and other Financial Institutions Available
} 
The whistleblower takes personal risks in exposing corruption. It is very important to have a comprehensive whistleblower legislative framework to sustain the success of the policy. As rightly noted by Banisar, ${ }^{1}$ the enactment of a comprehensive, dedicated law will serve as an effective legislative means of providing whistleblower protection because it will give the law visibility, thereby making the promotion of the law easier for governments and organisations. He noted further that a dedicated legislation will allow for the same law and regulation to apply to both public and private sector employees. The enactment of a dedicated whistleblower protection legislation will also ensure clarity because types of impropriety that can be reported will be specified in the Act.

\subsection{Anti-Corruption Value of Whislteblowing in Nigeria}

Whistleblower Protection is key in the fight against corruption and mismanagement, especially of public funds, and to strengthening transparency and accountability within organisations and society. Corruption is often not an easy to detect since it is covertly committed . It is therefore important that employees and those who know about corrupt practices voluntarily provide this information because their information and testimony facilitates the investigation and resolution of corruption cases. ${ }^{2}$ Whistleblower Protection is essential in encouraging the reporting of fraud, misconduct and other forms of corruption because public exposure will force change in some organisations. $^{3}$

Since the inception of the Whistleblowing Policy there has been significant recovery of looted funds, arrest and prosecution of alleged corrupt officials. For instance, a total sum of $\$ 43.4$ million was kept in an Apartment (7B) at Osborne Towers, Ikoyi, Lagos . This only came to limelight because someone reported. Furthermore, the EFCC uncovered bundles of naira notes totaling N450 Million inside bags at shop LS64 Legico Plaza, Nigerian Air Force Camp, Victoria Island, Lagos State. The sum of $\$ 9.8$ million was also recovered from the former Group Managing Director of the Nigerian National Petroleum Corporation, (NNPC), Mr. Andrew Yakubu, on February 3, 2017. In a shop in Balogun Market Lagos, the sum N250 million was also discovered ${ }^{4}$ At the Kaduna Airport, the sum of N49 million was discovered by the EFCC. The sum of \$151 million was also seized from a fake account in a commercial bank. ${ }^{5}$

Considering the level and cost of corruption in Nigeria, it is bewildering that a Whistleblower Protection

Bill has not been enacted since it was first sponsored in 2008 and then in 2009 and very in 2015. The enactment of a law to protect Whistleblowers holds great promise in breaking the shackles of corruption in Nigeria. As will be seen, to be effective whistleblower laws must be examined in the overall context of a country's legal and political sophistication, as well as its social and economic realities. ${ }^{6}$

During the $7^{\text {th }}$ Assembly, two bills were pending before the National Assembly on whistleblowing and protection of whistleblowers. The first one is the Bill sponsored by Senator Ganiyu Olanrewaju Solomon captioned "Whistleblower Protection Bill, 2008 (HB117) to provide for the manner in which individuals may, in the public interest disclose information that relate to unlawful or other illegal conduct or corrupt practices of others and the protection against victimization of persons who make these disclosures. The second bill known as Safeguarded Disclosure (Whistleblowers, Special Provisions, Etc.) Bill, 2009 (HB 167) sponsored by honourable John Halims Agoda seeks to make provision for the procedure by which persons employed in the public and private sectors may disclose information regarding unlawful conduct in workplace and to provide protection against any occupational detriment or reprisals of a person making such disclosures. These bills have not been re-presented.

As observed by Transparency International, oftentimes whistleblowers often suspect wrongdoing without having formal evidence. Also, given that whistleblowers are usually employees of companies where they blow the whistle, they may face specific risks which are normally not covered by witness protection laws such as harassment at work or dismissal. Furthermore, in terms of remedies for retaliation, they may need compensation for salary losses and career opportunities. Witness protection laws are therefore not sufficient to protect

https://www.cbn.gov.ng/out/2014/fprd/circular\%20on $\% 20$ code $\% 20$ of $\% 20$ circular $\% 20$ on $\% 20$ corporate $\% 20$ governance $\% 20$ and $\% 20$ whistle $\%$ 20blowing-may\%202014\%20(3).pdf (June 23 2017).

${ }^{1}$ Banisar, D. (no.11)

2 .Popescu L., A Critical Analysis of Whistleblower Protection In The European Union Available http://www.jopafl.com/uploads/issue7/A_Critical_Analysis_Of_Whistleblower_Protection_In_The_European_Union.Pdf (June 16 2017) ${ }^{3}$.Schultz, D. Harutyunyan K. (no.13).

4 Enejeta, E. 'Nigeria Whistleblowing Policy An Urgent Case for A Whistleblower Protection Law Available http://www.financialwatchngr.com/2017/05/07/nigerias-whistleblowing-policy-urgent-case-whistle-blowers-protection-law/

${ }^{5}$ As of April 2017 a total of 282 Nigerians provided 154 leads in three months since December 2016. The Ministry of Finance confirmed that a total of N11.635 billion has since been recovered and is set to reward about 20 whistleblowers with N375.8 Million. See Vanguard Newspaper, Available http://www.vanguardngr.com/2017/04/whistleblower-fg-nets-n73-billion-4-months/

${ }^{6}$ Luxford (no.15)

${ }^{7}$ Vanguard Newspaper, Senate passes Witness Protection Bill Available http://www.vanguardngr.com/2017/06/senate-passes-witnessprotection-bill/ June 12 2017. It was passed on Thursday $8^{\text {th }}$ June 2017 by the Senate. 
whistleblowers ${ }^{1}$.

The Bill which is relevant to our discourse is the Whistleblower Protection Bill 2015. It has passed the second reading at the Senate. The bill seeks to facilitate the disclosure of improper conduct by public officers and public bodies, protect persons making those disclosures and others from reprisals. It has 57 sections. The Public Complaints Commission is the oversight body. A Commissioner is authorised to receive complaints from whistleblowers.

\subsection{Whistleblower Protection Bill (WPB) 2015 (SB 158)}

To determine the effectiveness of any Whistleblower Protection Law, the following areas which are considered best practices are focussed on (1) scope and clarity of legislation, (2) mechanisms for disclosure, (3) protection of identity, (4) protection against retaliation, and (5) remedies available for wronged whistleblowers. ${ }^{2}$ Some areas of The Whistleblower Protection Bill (WPB 2015) are reviewed against the back drop of International best practices.

\section{a The Scope and Clarity of Legislation}

Scope of the protection offered by the legislation should be wide enough to accommodate both public and private worker according to Transparency International, legislative protections should apply to all whistleblowers, regardless of whether they work in the public or private sector. ${ }^{3}$ Types of disclosures covered should cover disclosure that would be accepted in a legal forum as evidence of significant misconduct or would assist in carrying out legitimate compliance functions. ${ }^{4}$ Clarity of the Whistleblower legislation is very important .Clarity may require setting out a more detailed list of the types of wrongdoing covered by the legislation in order for a thorough understanding of the law.

The WPB 2015 is restrictive in this respect as it only addresses workers in the public sector. Section 1 of the Bill states the purpose of the Bill as'facilitate disclosure of improper conduct by public officers and public bodies The Bill also fails to mention specific disclosure that may be regarded as wrongdoing. In section 8 of the WPB 2015, it is provided that any person that makes a protected disclosure in accordance to Part 11 of the bill is protected from criminal, civil and administrative liability arising from the protected disclosure. ${ }^{5}$ Although what constitutes improper conduct is enumerated, ${ }^{6}$ a clear definition stating the disclosures that are afforded protection should be provided in order to ensure legal certainty and clarity to potential whistleblowers. It is useful to specify the acts that constitute violations in any legal hierarchy, mismanagement, abuse of authority, and dangers to the public health. ${ }^{7}$

\section{b Mechanisms for Disclosure}

The first line of reporting is recommended by Transparency International through the establishment and maintenance of internal systems of disclosure, which offer the benefits of ease and accessibility to whistleblowers. ${ }^{8}$ This however should not preclude reporting to external bodies such as the media because and as noted by Luxford ,circumstances of the particular case may make a certain avenue of disclosure more appropriate than another, and a variety of channels need to be available to match the circumstances to allow whistleblowers the choice of channel they trust most to use. ${ }^{9}$ Section 3 of the WPB 2015 provides that disclosure can be made to the Commissioner ; that is the Commissioner of the Public Complaints Commission. No other person or entity is mentioned. It does not specify if disclosure can be made internally in the public office first and externally to the media, police or other external bodies. Again this is not broad enough. This reporting

${ }^{1}$ OECD Available <http://www.oecd.org/officialdocuments/publicdisplaydocumentpdf/?cote=GOV/PGC/ETH(2014)4\&docLanguage June 132017

${ }^{2}$ Luxford (no.31)

Transparency International, "Whistleblower Protection and the UN Convention Against Corruption" Available http://www.transparency.org/whatwedo/publication/whistleblower_protection_and_the_un_convention_against_corruption>. accessed 17 May 2017.

4 Devine T., Walden, S "International Best Practices for Whistleblower Policies" Available https://www.whistleblower.org/sites/default/files/pictures/Best_Practices_Document_for_website_March_13_2013.pdf May 172017.

${ }^{5}$ Section 2(a) and (b) of the WPB 2015 provides for natural persons who on reasonable grounds believe that a public officer or a public body has engaged or is engaging or proposes to engage in an improper conduct in their capacity as public officers or public bodies and has taken or proposes to take detrimental steps in contravention of section 15 . What is improper conduct? In the Interpretation, section 56; improper conduct is listed from a-d as criminal offence, failure to comply with legal obligation, miscarriage of justice and concealment of the foregoing. As regards specificity of crime, the bill falls short of effective protection This can be subject of litigation when the bill is enacted. ${ }^{6}$ See section 56 the Interpretation section WPB 2016, a) where criminal offence has been committed or is likely to be committed b) Where a person has failed, is failing or is likely to fail to comply with any legal obligations that he is subject to, c) that miscarriage of justice has occurred or is likely to occur d) information that pertains to the preceding paragraphs has been is being and is likely to be concealed.

${ }^{7}$ OECD Whistleblower Protection: Encouraging Report Available http://www.oecd.org/cleangovbiz/toolkit/50042935.pdfOECD 2012 June 242017.

8 Transparency International, "Recommended Draft Principles for Whistleblowing Legislation" Available https://www.transparency.org/files/content/activity/2009 PrinciplesForWhistleblowingLegislation EN.pdf (June 26 2017)

'OECD, “Committing to Effective Whistleblower Protection" (OECD, 2016) Available http://dx.doi.org/10.1787/9789264252639-en (June 24 2017). 
mechanism is restrictive. Both Internal and external disclosure mechanisms should be provided in the Bill . It is also important for whistleblowers to be informed of decisions taken on the basis of their report ${ }^{1}$

\section{c Protection of Identity}

There are divergent views as to the appropriate best practice in relation to protection of identity. The general consensus however is recognition of the need for ensuring whistleblower confidentiality. ${ }^{2}$ It is the suggestion of Transparency International that the identity of a whistleblower be protected in legislations as well as allow for anonymous disclosure. ${ }^{3}$ This is clearly to protect the whistleblower from danger and other forms of reprisal. It has been suggested that allowing anonymous disclosures might increase the volume of disclosures so as to make reporting systems less effective and increase the difficulty of investigations. ${ }^{4}$ The use of technology such as proxy e-mails, which allow two-way communication appears to be a remedy for the problem of investigations and evidence in courts. ${ }^{5}$

Section 4 of the WPB 2015 provides for anonymous disclosure. The whistleblower's identity is protected and in section 5 of the Bill the whistleblower is allowed to make disclosure about persons or bodies even when the identities of those who have engaged in the misconduct is unknown. Although this is a welcome development considering the fact that the culture of whistleblowing is relatively new, it is doubtful if the whistleblower can be a compellable witness in court. ${ }^{6}$ There is a lot of resistance from corrupt officials and organisations; it is very important that identities of whistleblowers are protected as the Witness Protection Bill 2016 has not been enacted. As noted by Luxford, to be effective whistleblower laws must be examined in the overall context of a country's legal and political sophistication, as well as its social and economic realities. ${ }^{7}$

\section{d Protection against Retaliation}

The very essence of whistleblower protection legislation is protection against retaliation. Political will on the part of government is a driving force in guarding against retaliation. As observed by Devine and Walden 2013 whistleblowers have risked retaliation thinking they had genuine protection while relying on rights contained in whistleblower laws. ${ }^{8}$

The WPB 2015 provides for protection against reprisal in section 13 from persons who take detrimental action against the whistleblower. Such a person shall be liable to 300,000 fine or a term of imprisonment for up to two years or both. Section 14 provides for proceedings for damages in tort and any other proceedings to recover damages . The designated court is the Federal High Court ${ }^{9}$ for an order requiring the person who has perpetrated the detrimental act to remedy same and an injunction. This protective measures against retaliation is commendable. The Bill however fails to take into cognisance physical threats to life of the whistleblower and family members. Although the WPB 2015 provides for secondment of police officers for certain investigations it does not state what type of investigation would warrant this nor provide for police protection of the whistleblower from reprisals. Police protection should be added to the WPB 2015.

\section{e) Remedies}

When retaliation cannot be prevented and whistleblowers face reprisals, adequate and timely compensation is necessary. Compensation should be broadly defined to cover all losses and seek to place the person back in an identical position as before the disclosure. ${ }^{10}$ Under sections 14 and 15 of the WPB 2015 proceedings for damages for reprisals is stated; the whistleblower can apply to the Federal High Court where he believes that detrimental action has been taken or is about to be taken against him. This measure implies that the whistleblower can apply to court to stop detrimental action such as dismissal or suspension before it is carried out. A glaring omission in the WPB 2015 is the monetary rewards from recovered loot as announced by the Ministry of Finance. The success recorded so far by the policy 1 believe is hinged to a large extent on the monetary rewards especially if one considers the level of deprivation that corruption has plunged the country into. The monetary reward included in the policy should be included in the law because it will encourage people to speak out

\subsection{Is the Whistleblower adequately Protected?}

A whistleblower risks a lot of things by blowing the whistle such as intimidation, harassment, dismissal or

\footnotetext{
${ }^{1}$ T. Devine; S. Walden (no 36)

${ }^{2}$ Luxword, (no 34)

${ }^{3}$ Transparency International (no 40).

${ }^{4}$ OECD, (no 41). 04741 Person Guide eBook.pdf( June 24 2017).

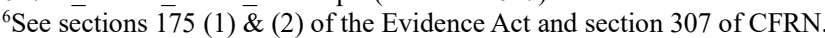

${ }^{7}$ Luxford, (no.43).

${ }^{8}$ Devine, T. Walden, S (no 43)

${ }^{9}$ Section 15 WPB 2015.

${ }^{10}$ Banisar, D. (no. 26)
}

${ }^{5}$ United Nations Office on Drugs and Crime, "The United Nations Convention against Corruption: Resource Guide on Good Practices in the Protection of Reporting Persons Available https://www.unodc.org/documents/corruption/Publications/2015/15- 
violence in the work place. For instance, Honourable Jibrin, a member of the House of Representatives representing Kano State, accused the speaker Yakubu Dogara and other members of the house of budget padding. He provided the police with information that the 2016 Budget was inflated to the tune of about N40bn.He was suspended for 180 days and he went on exile because he was afraid for his life. ${ }^{1}$

Another whistleblower sacked in February 23, 2017, for exposing fraud to the tune of $\$ 229,000$ and N800,000.at the Ministry of Foreign Affairs in 2016, Mr. Ntia Thompson, was reinstated after several civic groups had called for his reinstatement.

Mr. Aaron Kaase, who alerted the government to the perpetration of N11.750 million in the Police Service Commission (PSC) was suspended without pay and has been persecuted based on his petition upon which ICPC launched an investigation into and caused the PSC to refund $\mathrm{N} 133 \mathrm{~m}$ to government coffers, and charged one $\mathrm{Mr}$ Ibe for the said fraud. Mr. Kaase is standing trial on trumped up charges. Mr. Murtala Ibrahim, an auditor of the Federal Mortgage Bank of Nigeria, was sacked for blowing the whistle and refusing to cover up a contract scam and false financial report of the bank. ${ }^{2}$

One Mr Ahmed Echodo was arrested and charged to court in an Abuja Upper Area Court sitting in Gudu, in Nigeria's Federal Capital Territory for allegedly giving false information about the deputy senate president. The Police searched the building after and found nothing incriminating Before then the Deputy Senate President had notified the Senate of an anonymous letter to him alleging that there was a plan by the EFCC to raid buildings associated with him and plant incriminating items in it under the cover of whistle blower policy. ${ }^{3}$

In all these scenarios, the whistleblowers could have gone to court to stop detrimental action taken against them had the WPB 2015 been enacted. Section 2 of the Bill provides that a natural person who believes on reasonable grounds and discloses that a public officer or public body has engaged in an improper conduct may apply under section 15 by way of injunction or an action of remedy. From the foregoing, a whistleblower is not adequately protected. The absence a dedicated whistleblower legislation is important in order to sustain the success garnered especially if one considers how fiercely corruption has been fighting back.

\subsection{Conclusion}

Protection of the whsitleblower is vital in fighting corruption. The House of Assembly should therefore expedite action in enacting the WPB 2015 but not without reviewing it in accordance with International Best Practices. A robust legislative framework equals a bold whistleblower. The enactment of a comprehensive, dedicated law as the basis for providing whistleblower protection is generally considered the most effective legislative means of providing such protection. The WPB 2015 should be reviewed to cover both private and public employees and the disclosures that will be protected should be clearly stated. Police Protection should also be incorporated into the bill in addition to provisions on monetary incentives. The foregoing must be matched with a strong political will on the part of government and support from other stakeholders such as the media and civil societies to ensure adequate legislative framework to protect whistleblowers in the fight against corruption.

\footnotetext{
1 Nigeria Times, Jibrin, The Whistleblower as Victim Available http://nigeriantimes.ng/politics/jibrin-the-whistleblower-as-victim/ (June 26 2017).

2 Odunsi, W. Daily Post , 'Federal Mortgage Bank sacks Whistleblower Available http://dailypost.ng/2017/06/12/federal-mortgage-banksacked-murtala-ibrahim-blowing-whistle-africmil-tells-fashola (June 23 2017).

3 Tsa, G. Sun Newspaper, Whisleblower on Ekweremadu land in Trouble. Available http://sunnewsonline.com/whistle-blower-onekweremadu-lands-in-trouble/Godwin (June 20 2017).
} 